\title{
Analisis Strategi Konten Dalam Meraih Engagement pada Media Sosial Youtube (Studi Kasus Froyonion)
}

\author{
Ricko, Ahmad Junaidi \\ surelricko@gmail.com,ahmadd@fikom.untar.ac.id \\ Fakultas Ilmu Komunikasi Universitas Tarumanagara
}

\begin{abstract}
The use of new media is increasing in the midst of society, and new media also function as social media. With a large market, social media is an opportunity to attract a large and broad audience. Audience withdrawal is done through content uploaded on social media. This also attracts many companies and institutions to plunge into creating content on social media to achieve their goals and audience needs. This study aims to try to examine the content strategy carried out by one company, Froyonion, in gaining engagement on social media Youtube. The theory that the author uses as the basis of this research is the theory of new media, social media, content, content strategies and interpersonal communication. This research was conducted using a descriptive qualitative approach with a case study method. The method of data collection is done through interviews, observation, literature studies, and online data search. Interviews were conducted on 3 speakers, namely Creative Director Froyonion, content strategist and social media specialist. The results of this study indicate that the content strategy that Froyonion performed on their content was based on planning with appropriate considerations. Starting from the message thrown, the delivery strategy, visual design, targets and benchmarks, to the technical things that need to be done on social media Youtube.
\end{abstract}

Keywords: Social Media, Content Strategy, Engagement

\begin{abstract}
Abstrak
Penggunaan media baru semakin meningkat di tengah masyarakat, media baru pun berfungsi sebagai media sosial. Dengan pasar yang besar, media sosial menjadi peluang untuk menarik audiens yang besar dan luas. Penarikan audiens dilakukan melalui konten-konten yang diunggah di media sosial. Hal ini pun menarik banyak perusahaan maupun lembaga untuk terjun membuat konten di media sosial demi mencapai tujuan mereka dan kebutuhan audiens. Penelitian ini bertujuan untuk mencoba meneliti strategi konten yang dilakukan salah satu perusahaan yakni Froyonion dalam meraih engagement pada media sosial Youtube. Teori yang penulis gunakan sebagai landasan penelitian ini adalah teori new media, media sosial, konten, strategi konten dan komunikasi interpersonal. Penelitian ini dilakukan menggunakan pendekatan kualitatif deskriptif dengan metode studi kasus. Metode pengumpulan data dilakukan melalui wawancara, observasi, studi pustaka, dan penelusuran data online. Wawancara dilakukan terhadap 3 narasumber yaitu Creative Director Froyonion, ahli strategi konten, dan spesialis media sosial. Hasil dari penelitian ini menunjukkan bahwa strategi konten yang dilakukan Froyonion pada konten mereka telah berdasarkan perencanaan dengan pertimbangan-pertimbangan yang sesuai. Mulai dari pesan yang dilempar, strategi penyampaian, desain visual, target dan tolok ukur, hingga hal-hal teknis yang perlu dilakukan dalam media sosial Youtube.
\end{abstract}

Kata Kunci: Media sosial, strategi konten, engagement 


\section{Pendahuluan}

Pada masyarakat kontemporer, informasi telah menjadi bagian yang sangat penting; ketergantungan terhadap informasi sangat tinggi untuk memahami dunia dan segala aspek di dalamnya. Media, dalam situasi ini, juga turut mengonstruksi dunia sesuai dengan kerangka realitas yang dipahaminya. Media massa kini berperan bukan hanya sebagai sarana untuk memperoleh informasi tentang suatu hal, melainkan kehadirannya juga dinanti. Kebutuhan terhadap media massa dan informasi sangat tinggi dan mendominasi aktivitas masyarakat menyebabkan media dan informasi terkadang menjadi lebih dekat dari anggota keluarga yang lainnya. (Wahid, 2014)

Media massa memiliki ciri dan karakteristik masing-masing guna memenuhi kebutuhan masyarakat yang luas dan heterogen. Mulai dari media cetak hingga media elektronik. Kemajuan teknologi yang pesat dan terus berkembang pun turut mendukung pemenuhan kebutuhan akan informasi dan komunikasi yang pada akhirnya melahirkan sebuah media baru. Jangkauan yang semakin luas, ditambah kemudahan dan murahnya akses membuat pengguna internet meningkat pesat. Informasi pun dapat diakses dengan mudah, cepat, dan murah oleh siapapun yang memiliki jaringan kapan pun dan dimana pun. Penggeseran media pun terjadi ke arah media baru. Media baru menjadi media komunikasi yang diandalkan bahkan digandrungi oleh masyarakat. Wahid (2016: 79) mengatakan media baru menawarkan kapasitas untuk memperluas volume informasi yang memungkinkan individu memegang kontrol lebih besar dan kapasitas menyeleksi informasi tertentu yang mereka harapkan dapat terima. Wearesocial Hootsuit dalam laporan riset yang dirilisnya pada Januari 2019 mengungkapkan pengguna media internet di Indonesia mencapai 150 juta atau sebesar 56\% total populasi. Angka ini meningkat dari tahun sebelumnya yang berjumlah 143 juta pengguna. Dengan banyak dan terus meningkatnya jumlah pengguna media digital, memunculkan peluang besar untuk menarik perhatian masyarakat di media ini. Hal ini pun turut dimanfaatkan oleh berbagai pihak termasuk banyak perusahaan dan lembaga sebagai sarana komunikasi dan menyebarkan informasi.

Kehadiran media baru semakin memudahkan dalam berkomunikasi dan pola komunikasi masyarakat dapat terus berlangsung. Media baru pada akhirnya berfungsi sebagai sosial media. Kotler dan Keller dalam bukunya Marketing Management (2012: 568) mengatakan media sosial merupakan sarana bagi konsumen untuk berbagi teks, gambar, audio, dan informasi video dengan satu sama lain dan dengan perusahaan dan sebaliknya.

Schiffman dan Kanuk (dalam Marta, 2016) mengungkapkan kelebihan media sosial adalah addressable, yakni pesan dapat disampaikan secara khusus meskipun penerima pesan yang lain dapat menerima esensi pesan yang sama, dan interaktif, dalam arti penerima pesan dapat berinteraksi secara khusus dengan pengirim pesan, dan bahkan ia bisa dengan mudah menyebarkannya. Dengan media sosial, pengguna dapat membangun percakapan bahkan komunitas, karena media sosial juga mempermudah pertemuan beberapa atau banyak orang dengan minat sama. Media sosial pada dasarnya merupakan situs atau layanan daring (online) yang memungkinkan penggunanya tak hanya mengonsumsi, tapi juga berpartisipasi membuat, mengomentari, dan menyebarkan beragam konten dalam berbagai format: teks, gambar, audio, atau video.

Cangara (2017) mengungkapkan di tengah riuhnya penggunaan platform digital sebagai medium komunikasi, hal yang paling harus diperhatikan dalam 
platform ini adalah formulasi konten atau pesan yang akan dikomunikasikan kepada audience. Pesan atau konten merupakan unsur komunikasi yang sangat penting. Menurut Cangara (2017), secara umum pesan adalah segala sesuatu yang disampaikan oleh seseorang dalam bentuk simbol dan dipersepsi dan diterima oleh khalayak dalam serangkaian makna. Maka dari itu, dalam penggunaan medium ini juga tentu perlu diiringi dengan strategi yang tepat agar komunikasi memberikan makna dan hasil yang memuaskan dan diharapkan.

Strategi konten digunakan sebagai peta untuk mengarahkan konten guna mencapai dan memenuhi tujuan dari website dan konsumen. Penyampaian informasi melalui konten harus dapat dengan jelas tersampaikan dan memenuhi kebutuhan pengunjung terkait informasi yang dicari sekaligus memberikan dampak. Sehingga konten tersebut dapat dikatakan berguna dan berkualitas secara tujuan dan bagi masyarakat. (Halvorson, 2009)

Froyonion ialah salah satu perusahaan yang memanfaatkan media sosial guna menyebarluaskan konten-konten. Froyonion sendiri juga menyisipkan pesan tertentu yang ingin disampaikan kepada masyarakat melalui kontennya lalu didistribusikan di media sosial, khususnyaYoutube. Kanal Youtube Froyonion saat ini telah menembus jumlah subscriber subscriber 280 ribu subsriber.

Maka dari itu, rumusan masalah dalam penelitian ini ialah bagaimana strategi konten dalam meraih pada engagement pada media sosial Youtube. Tujuan dengan dilakukannya penelitian ini adalah menggali strategi konten yang dilakukan Froyonion dalam meraih engagement pada media sosial Youtube.

\section{Metode Penelitian}

Penulis melakukan penelitian dengan pendekatan kualitatif deskriptif. Bogdan dan Taylor (Moleong, 2010: 4) menjelaskan metode penelitian kualitatif merupakan sebuah prosedur penelitian yang menghasilkan data deskriptif berupa kata-kata tertulis maupun lisan dari orang-orang maupun perilaku yang dapat diamati. Muri Yusuf (2014: 329) menjelaskan penelitian kualitatif merupakan suatu strategi inquiry yang menekankan pencarian makna, pengertian, konsep, karakteristik, gejala, simbol, maupun deskripsi tentang suatu fenomena, fokus, dan multimetode.

Metode yang dipakai dalam pendekatan ini ialah, studi kasus. Creswell (2010: 20) mengungkapkan studi kasus adalah strategi penelitian dimana di dalamnya peneliti menyelidiki secara cermat suatu program peristiwa, aktivitas, proses atau sekelompok individu. Penelitian studi kasus memusatkan diri secara intensif pada satu objek yang mempelajarinya sebagai suatu kasus. Muri Yusuf (2014: 39) mengatakan apabila seseorang ingin memahami latar belakang suatu persoalan, atau interaksi individu di dalam unit sosial atau mengenai suatu kelompok individu secara mendalam, utuh, holistik, intensif, dan naturalistik. Maka penelitian kasus merupakan pilihan utama dibandingkan dengan jenis penelitian kualitatif yang lain. Dalam hal ini, penulis melakukan

Teknik pengumpulan data dilakukan dengan wawancara mendalam pada Creative Director Froyonion, Arie Je. Menurut Bungin (2007: 115), wawancara mendalam atau interview merupakan suatu proses memperoleh data atau keterangan yang tujuan untuk penelitian dengan cara tanya-jawab, sambil bertatap muka antara pewawancara dengan informan atau orang yang diwawancarai, dengan atau tanpa menggunakan pedoman wawancara, dimana pewawancara dan informan terlibat 
dalam kehidupan sosial yang relatif lama. Dalam melengkapi hasil temuan bagaimana strategi konten yang dilakukan, penulis juga mewawancarai ahli strategi konten, Ade Putri Paramadita dan ahli sosial media, Fina Labida Fahinta. Pengumpulan data juga dilakukan melalui studi pustaka yang mempelajari strategi konten, media baru, media sosial, juga komunikasi interpersonal. Penelusuran data online dilakukan untuk melengkapi studi pustaka yang ada dan mendalami temuan pada kanal Youtube Froyonion. Menurut Nazir (2013: 93) Studi pustaka adalah teknik pengumpulan data dengan mengadakan studi terhadap buku-buku, dan laporan-laporan yang ada hubungannya dengan masalah yang akan dipecahkan. Sedangkan menurut Bungin (2011), Metode Penelusuran data online adalah cara untuk penelusuran data melalui media online seperti internet dan media jaringan lainnya yang menyediakan fasilitas online.

Teknik analisis data yang penulis gunakan adalah secara induktif. Menurut Mulyana (2008:156), Induksi adalah proses dengan mana peneliti mengumpulkan data dan kemudian mengembangkan suatu teori dari data tersebut. Penulis berangkat dari hasil wawancara mengenai strategi konten yang telah dilakukan oleh Froyonion pada kanal media sosial Youtube. Hasil wawancara yang telah didapat kemudian dirumuskan menjadi model, konsep, teori, pinsip, proposisi, atau definisi yang berhubungan dengan strategi konten. Miles dan Huberman (dalam Sugiyono 2016: 91) mengemukakan bahwa ada tiga aktivitas dalam analisis data yaitu reduksi data, penyajian data, dan penarikan kesimpulan atau verifikasi.

\section{Hasil Temuan dan Diskusi}

Dalam penelitian ini, penulis menemukan berbagai macam strategi yang dilakukan dalam penerapan strategi konten Froyonion. Dalam pembuatan konten Froyonion sendiri, pesan yang ingin dilempar ialah kelokalan yang belum tentu arif. Kelokalan yang belum tentu arif disini sebagai contoh di antaranya ialah paradigma kecanduan jika mencoba rokok, mitos pamali, ataupun minuman jamu beralkohol. Pesan ini didasari karena Froyonion menganggap sesuatu yang nyata ada di masyarakat perlu disebar dan tak perlu ditutupu seolah tidak ada. Informasi yang dibutuhkan masyarakat tidak selamanya hanyalah informasi baik, masyarakat berhak untuk mendapat informasi yang benar. Banyak hal yang dibicarakan di tengah masyarakat tapi belum dimengerti secara penuh dan jelas. Peristiwa ini menyebabkan banyaknya perilaku yang berdasarkan paradigma yang belum tentu benar. Tugas sebagai penyedia kontenlah untuk memaparkan kembali informasi secara terbuka dan jelas. Pesan kelokalan yang belum ntentu arif merupakan isi media yang menjelaskan pikiran, perasaan, keinginan, dan tujuan yang dirancang melalui perencanaan konten berdasarkan alasan dan tujuan.

Froyonion juga membuat berbagai program konten yang dimuat dalam playlist pada kanal Youtube. Hal ini dilakukan untuk menggaet berbagai audiens yang berbeda-beda. Jenis program konten yang dibuat diantaranya ialah bertema kuliner, fashion, dan teknologi. Froyonion percaya bahwa setiap orang memiliki irisan ketertarikan pada hal-hal tersebut meskipun sedikit. Konten-konten ini kemudian dijadikan penilaian dalam menentukan konten yang akan dibuat selanjutnya.

Froyonion dalam strategi penyampaian pesannya mencoba menjadi role yang anti tesis. Hal ini dilakukan dengan cara membantah suatu pemikiran tapi menggunakan bahasa sehari-hari. Strategi ini berharap dapat menyebabkan audiens untuk mempertanyakan kembali pemikiran yang dimiliki namun tidak merasa 
digurui. Dalam arti lain, menambah perspektif baru pada audiens. Media yang digunakan dalam mendistribusikan konten ini ialah video. Penggunaan media ini karena dianggap merupakan media yang paling mudah dicerna oleh audiens saat ini. Sehingga, pesan pun dapat tersampaikan dan mudah dicerna. Cara ini ditujukan untuk mempersuasi audiens demi mencapai tujuan konten.

Konten-konten hiburan juga dibuat guna mempertahankan penonton yang sudahh ada sekaligus menarik penonton baru. Porsi konten pun dibagi menjadi 50-50 untuk konten hiburan dan konten utama. Namun, hal terpenting yang dijaga ialah konten utama dengan benang merah kearifan yang belum tentu lokal tidak hilang. Bahasa Indonesia menjadi pilihan bahasa yang digunakan dalam konten Froyonion. Pemilihan ini tak lepas dari role anti tesis yang diperankan, mereka mencoba membantah tren gaya komunikasi bergaya bahasa campur Bahasa Indonesia dan Bahasa Inggris. Mereka juga ingin menyampaikan dan menjadi contoh bahwa penggunaan Bahasa Indonesia pun dapat menarik. Meskipun, sesuatu dilihat menarik bukanlah dari bahasa melainkan dari konteks dari konten.

Froyonion menggunakan warna neon dengan gradient kontras sebagai desain visual yang sekaligus menjadi branding mereka. Pemilihan desain ini dipengaruhi dengan persepsi yang melekat pada anak muda. Stigma tersebut pun mempengaruhi penilaian terhadap suatu konten. Dengan alasan tersebut, Froyonion pun menerapkannya sebagai jalan tengah dengan tujuan agar kebutuhan komunikasi dapat tersampaikan dan dimengerti. Gradien kontras digunakan untuk pengaplikasian di dalam video agar cepat di notice dan eye-catching. Desain menjadi bagian dari praktik perencanaan dalam mebuat, menyampaikan, menata, dan mengelola konten sebagai sesuatu yang bermanfaat. Desain merupakan bagian dari konten untuk bertugas mempresentasikan konten yang dikelola.

Froyonion memasang tolok ukur dengan berhasil membuat diskusi pada setiap konten yang diunggah. Video dianggap gagal jika terjadi bias dan tidak mencapai minimal 20 persen pada audiens yang membicarakan isi konteks dari konten. Dengan begitu, konten video semacam dirasa tidak perlu diproduksi lagi. Selain itu, target berupa angka viewers juga dipasang dengan minmal 50 ribu hingga 100 ribu views untuk masing-masing konten. Engagement dilihat pada jumlah interaksi yang diperoleh akun yang dikelola. Dalam Youtube, interaksi terjadi dalam komentar, shares, dan likes. Pemasangan tolok ukur merupakan komponen amat penting dalam mencapai tujuan dan dalam pembuatan strategi konten.

Froyonion dalam membuat konten tentu juga menghadapi masalah-masalah. Masalah yang dirasakan ialah banyak dan beragamnya variabel audiens yang ada saat ini. Hal ini membuat Froyonion sulit untuk membidik konten mana yang akan diberikan kepada audiens. Sehingga, dalam menghadapi masalah ini pun mereka memilih langkah tersendiri yaitu mencoba membuat semua konten yang dikira dapat menarik audiens. Langkah ini tentu juga dibatasi dengan menjaga pesan utama. Bereksperimen menjadi pelajaran berharga dan hal yang lumrah dalam pembuatan konten dan ide.

Konten dalam media sosial Youtube perlu untuk dilengkapi dengan sebuah judul. Judul diperlukan untuk memberi gambaran terhadap isi konten terkait. Froyonion dalam penetapan judul menggunakan standart penulisan headline. Judul dibuat click-bait namun tidak misleading dalam menarik penonton. Dalam setiap konten juga diberikan tag dan description yang berkaitan. Froyonion memilah-milah kata kunci yang penting dalam konteks kontennya. Tag yang digunakan juga 
dimasukkan pada description guna membantu video lebih mudah ditemukan audiens dalam mesin pencarian.

Beberapa kata kunci dapat memiliki nilai lebih jika sedang momentum dan menjadi pembicaraan. Dalam hal ini, froyonion juga membuat dua jenis konten yaitu konten yang bersifat long lasting dan bersifat mengejar trending. Segmentasi dalam konten ini juga merupakan strategi untuk menjaring audiens baru.

Setiap audiens memiliki kebiasaan dan waktu akses terhadap Youtube yang berbeda. Kebiasaan ini pula mempengaruhi waktu unggah video Froyonion. Froyonion dalam mengunggah kontennya juga melalui proses eksperimen untuk menemukan waktu yang paling tepat. Mereka bertumpu pada analytics sebagai penilaian terhadap waktu unggah konten mereka. Kegiatan pengecekan analytics sendiri dilakukan setiap satu bulan atau dua minggu sekali. Pada akhirnya, Froyonion saat ini telah menetapkan jadwal unggah konten mereka jatuh pada setiap hari Rabu dan Jumat pada pukul 19.00 WIB. Frekuensi unggah dua video perminggu disebabkan karena dalam menghasilkan sebuah konten diperlukan waktu dan tahapntahapan seperti perencanaan, produksi, penyuntingan, dan lainnya. Jadwal unggah mereka ini pun dikomunikasikan dengan mencantumkannya pada header profil kanal Youtube.

Setiap konten yang dibuat Froyonion melalui filter-filter untuk memastikan konten yang dibuat sesuai dengan tujuan dan dapat mempertemukannya dengan kebutuhan audiens. Arie Je selaku Creative Director Froyonion menjadi filter terakhir dalam setiap konten tersebut. Arie tidak selalu ikut serta dalam proses produksi, namun akan selalu hadir saat proses brainstorming dalam menentukan konsep konten dan juga proses penyuntingan untuk menentukan footage mana yang akan dimuat di dalam video.

Dalam melakukan penelitian ini penulis juga menemukan temuan berupa penggunaan akun media sosial Instagram yang dilakukan Froyonion. Akun Instagram mereka digunakan untuk memposting teaser-teaser video yang mereka unggah di Youtube. Bukan hanya memposting, kolom berisi komentar pun turut ditanggapi dalam akun Instagram mereka sehingga terjadi komunikasi. Fina Ladiba mengungkapkan hal iini merupakan lumrah sebagai promosi antar platform.

Penulis juga menemukan dilakukannya penyematan pada kolom komentar Youtube mereka. Fina mengatakan penyematan pada kolom komentar dapat dilakukan guna menambah hal atau bahasan. Penyematan komentar juga dapat membantu untuk menjadi room yang dibuat creator berisi saran-saran dari audiens.

\section{Simpulan}

Penulis menyimpulkan Froyonion telah menerapkan strategi konten dalam meraih engagement pada media sosial Youtube yang didasari dengan praktik perencanaan dengan pertimbangan-pertimbangan yang sesuai dalam menuju tujuan. Strategi konten dilakukan mulai dari pesan yang ingin dilempar melalui konten, strategi penyampaian pesan, desain visual, target dan tolok ukur, cara mengatasi masalah yang dihadapi, pemfilteran terakhir pada konten hingga hal-hal teknis seperti penetapan judul, tag, deskripsi pada konten video, frekuensi dan waktu unggah, penyematan pada kolom komentar, dan pemanfaatan multi-platform pada akun media sosial Instagram. 
Ricko, Ahmad Junaidi: Analisis Strategi Konten Dalam Meraih Engagement pada Media Sosial Youtube (Studi Kasus Froyonion)

\section{Ucapan Terima Kasih}

Penelitian ini dapat terwujud dengan kontribusi dari beberapa pihak. Untuk itu, penulis ingin mengucapkan terima kasih kepada pihak Fakultas Ilmu Komunikasi Universitas Tarumanagara yang telah memungkinkan pelaksanaan penelitian ini. Ucapan terima kasih juga penulis sampaikan atas ketersediaan pihak Froyonion untuk diteliti dan para narasumber ahli yang telah meluangkan waktu dan tenaga untuk memberikan tanggapan terkait penelitian penulis yaitu Fina Ladiba Fahinta sebagai social media specialist dan Ade Putri Paramadita sebagai ahli strategi konten. Terima kasih juga kepada bapak Ahmad Junaidi sebagai dosen yang telah membimbing penulis dengan sabar dan baik.

\section{Daftar Pustaka}

Bungin, Burhan. 2007. Penelitian Kualitatif: Komunikasi, Ekonomi, Kebijakan Publik dan Ilmu Sosial lainnya. Jakarta: Putra Grafika

Bungin, Burhan. 2011. Penelitian Kualitatif. Jakarta: Kencana Predana Media Group

Cangara, Hafied. 2017. Perencanaan dan Strategi Komunikasi. Jakarta: Rajawali Press

Creswell, J.W. 2010. Research Design: Pendekatan Kualitatif, Kuantitatif, dan Mixed. Yogyakarta: PT Pustaka Pelajar

Halvorson,K. 2009. Content Strategy for the Web, New Riders, Berkeley, CA.

Kotler, Phillip, Kevin Lane Keller. 2012. Marketing Management, 14th Edition. United States of America: Pearson

Marta, Rustono Farady., \& William, Denise Monica. 2016. Studi Terpaan Media Pemasaran Melalui Posting Instagram Terhadap Ekuitas Merek Pelanggan Sumoboo! ( Analisis Eksplanatif pada Komunitas Food Blogger \#WTFoodies). Jurnal Komunikasi, Volume 8, No: 1, Halaman 68-82

Moleong, L.J. 2010. Metodologi Penelitian Kualitatif. Bandung: Remaja Rosdakarya

Mulyana, Deddy. 2008. Ilmu Komunikasi: Suatu Pengantar. Bandung: Remaja Rosdakarta

Nazir, Moh. 2013. Metode Penelitian. Bogor: Ghalia Indonesia

Umaima, Wahid. 2016. Komunikasi Politik: Teori, Konsep, dan Aplikasi Pada Era Media Baru. Indonesia: Simbiosa Rekatama Media. Bandung. 